\title{
Effects of harvesting timber stands on goshawk nesting in two European areas
}

\author{
Vincenzo Penteriani ${ }^{a, *}$, Bruno Faivre ${ }^{b}$ \\ aDepartment of Applied Biology, Estación Biológica de Donana, Avda. de María Luisa s/n., Pabellón del Perú, \\ Apartado de Correos 1056, 41013 Sevilla, Spain \\ bLaboratoire Ecologie-Evolution, Université de Bourgogne, Faculté des Sciences de la Vie, 21000 Dijon, France
}

\begin{abstract}
We evaluated the effects of harvesting timber stands on goshawk (Accipiter gentilis) nesting in two European areas (central Italy and eastern France), by studying their occupancy and reproductive performance. We found no difference in the productivity of goshawk pairs reproducing in unlogged vs. logged stands. When considering the same nesting stand, before and after timber harvesting, we noted no differences in the number of young per breeding pair nor a year effect. We observed that $87.5 \%$ of goshawk pairs nesting in logged stands moved away only when the original stand structure was altered by $>30 \%$, and then only to the nearest neighbouring mature stand (maximum distance ca. $1.5 \mathrm{~km}$ ). The results of our study suggest that goshawks can tolerate some levels of timber harvesting within the nesting stand, as long as the cover reduction does not exceed the threshold of about $30 \%$..
\end{abstract}

Keywords: Goshawk; Accipiter gentiles; Timber harvesting; Productivity; Stand occupancy

\section{Introduction}

Forest management for timber production and wildlife has complex socio-economic and ecological implications. Balanced resource management requires an understanding of the animal species most vulnerable to forest alterations (Harris and Kangas, 1988). A thorough analysis of the requirements of these species, and of their modes of response to forest changes and alterations, can yield valuable data for strategic forest management planning and minimise the conflict between the use of woodland resource and the conservation of forest areas and wildlife. Raptors, in particular, should always be considered as key species in woodland resource management decisions, given their position in the forest food chain and their potentially important role in the ecological processes of forests (Niemi and Hanowski, 1997a).

Numerous studies have been conducted on raptors, especially on the relationships between forest species and stand structure and management practices (e.g. McCarthy et al., 1987; Thomas et al., 1990; Petty, 1998),

\footnotetext{
* Corresponding author.

E-mail address: penteriani@ebd.csic.es (V. Penteriani).
}

but we know very little about how avian species respond demographically to variations in the structure of logged stands (Niemi and Hanowski, 1997b). Many studies have placed emphasis on the goshawk (Accipiter gentilis) nesting habitat structure and demography in relation to forest structure (e.g. Reynolds et al., 1982; Crocker-Bedford and Chaney, 1988; Block et al., 1994; Toyne, 1997). As this species nests and hunts especially in old-growth and mature forests, concerns about potential conflicts between timber harvesting and maintenance of viable populations have been expressed both in the United States (e.g. Kennedy, 1988; CrockerBedford, 1990, 1998; Cooper and Stevens, 2000) and in Europe (e.g. Forsman and Ehrnsten, 1985; Kenward et al., 1991; Widen, 1997). Many North American authors suggested that timber harvesting may result in reductions in goshawk abundance and nest reoccupancy (e.g. Reynolds et al., 1982; Hall, 1984; Crocker-Bedford, 1990; Iverson et al., 1996), because several factors have negative effects on goshawk populations (e.g. loss of breeding and wintering habitat, increased predation and competition, changes in micro-climate conditions, reduction in prey abundance and availability). Modern forest management practices appear to have a similar 
negative effect in Europe, because changes in the forest landscape may reduce the quality of goshawk nest sites and hunting ranges (Widen, 1997).

Although a number of studies describe the structural characteristics of goshawk nest stands, and management guidelines have been issued to maintain or enhance goshawk nesting habitats (e.g. Reynolds et al., 1992; Graham et al., 1994; Iverson et al., 1996), few data are available on the effects of logging within the nest stand on stand occupancy and goshawk productivity. In effect, the proposed management guidelines were based essentially on descriptive and correlative studies on the habitat structure, that is, on an indirect approach and without direct elements on the response of the species to progressive alterations of its nesting stand due to the logging steps. Moreover, no one has demonstrated what the long-term effects are on goshawk demography, mainly because several years are necessary to observe the reaction of a reproductive pair between the first light-thinning stage and final felling. The only study that experimentally tested some forest recommendations for maintaining goshawk reproduction seemed to show their inadequacy (Crocker-Bedford, 1990), and suggested that the species was very sensitive to stand alterations.

Such issues in the United States raise a number of questions: are we underestimating the impact of the timber harvesting on European populations of goshawks? Are Palearctic goshawk populations as sensitive to nesting stand logging as Nearctic ones, and do they need the same political and management attention in Europe as in North America? We, therefore, examined the effects of timber harvesting through shelterwood logging on goshawk nesting stands in two European areas (one in central Italy and the other in eastern France), by comparing goshawk occupancy and reproduction performance in unlogged and logged nesting stands. During this long-term study, we also had the opportunity to assess the logging effects on the same nesting stand before and after timber harvesting.

\section{Study areas}

The Italian nest sites (studied from 1984 to 1995; Penteriani, 1997; Penteriani and Faivre, 1997) were located in the Abruzzi region (central Italy), in an area of the Apennine mountains including the Abruzzi and Majella National Parks, and the Sirente massif. This area, ranging in elevation from 800 to $2300 \mathrm{~m}$, predominantly consists of beech (Fagus sylvatica) forested slopes with grazing and fallow farmland in the valleys. Above $1900 \mathrm{~m}$, high-altitude pastures replace forests.

The French nest sites (studied from 1993 to 1999; Penteriani, 1999a,b) were located in a forested area of Burgundy (Cote d'Or, eastern France). This area, ranging in elevation from 180 to $590 \mathrm{~m}$, is dominated by wide and homogeneous tracts of broad-leaved trees, occasionally intercalated with small areas of cropland. Depending on soil conditions and microclimate, the forests may be locally dominated by Quercus pedunculata, Quercus petraea or F. sylvatica.

\subsection{Forest treatments}

The high forest system of both study areas is similar in terms of stand structure, scale and pattern of felling steps, method of regeneration and length of rotation. In both areas, new-growth is established mainly by the shelterwood system, characterised by clearance of the mature stand in successive felling steps (Harris and Harris, 1991; Peterken, 1996). The harvesting of mature and old-growth stands, which represent the typical nesting habitat of goshawks in both study areas (Penteriani and Faivre, 1997; Penteriani, 1999b), starts with a first light thinning, removing $10 \%$ of the stand trees. The regeneration process continues with four stages three progressive steps of $20 \%$ felling and a final $30 \%$. The time between the first thinning and the final removal is quite different for each mature stand (generally 10-15years, namely tree removal once every 2-3 years), because it chiefly depends essentially on political, management and recreational choices, or other local factors. The forestry operations are generally carried out from mid-September to mid-April, although in some cases the logging may take place in late spring and summer too (e.g. local snowy conditions). The full cycle of felling operations covers stands of ca. 10 ha in France (Ferry and Frochot, 1990), sometimes less in Italy (Sulli and Bernoni, 1993).

\section{Data analysis}

\subsection{Comparisons between the Italian and French populations}

Before evaluating the effects of logging on goshawks, we investigated whether there were significant differences in nest site preferences, productivity (mean number of young fledged per breeding pair and per successful pair; Steenhof, 1987) and diet between the two European samples, so as to determine whether intra-population factors other than logging might affect the subsequent analysis. For this comparison, we used three approaches. We used four variables to describe the nest tree: total height, diameter at breast height ( $\mathrm{dbh}$, crown volume, mean distance to the four nearest surrounding trees. Likewise, for the nesting stand, we estimated the tree height, dbh, trunk height, tree crown volume, mean distance between trees, canopy cover, flight space [for the description and computation of the above-mentioned variables, see Penteriani and Faivre 
(1997)] within a 1-ha plot around the nest tree. A discriminant function analysis (DFA) was then used to examine differences in nesting stand structures between Italian and French sites, before and after stand timber harvesting. A chi-square analysis tested the significance of the geographic site classification established from this DFA procedure (Sokal and Rohlf, 1995). Secondly, a Mann-Whitney U-test was used to detect possible differences in Italian vs. French goshawk productivity in unlogged stands; as the number of the years during which each pair was checked was different, we used the mean number of young to avoid pseudoreplication. Thirdly, an adaptation of the Pianka's index (Marti, 1987) was used to compare Italian vs. French goshawk diet:

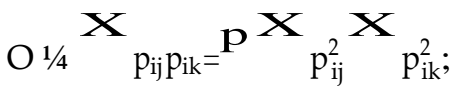

where $p_{i j}$ and $p_{i k}$ are proportions of main prey species in the diet of the Italian and French goshawks (Columba palumbus, Garrulus glandarius, Turdus viscivorus, Turdus philomelos, Glis glis, Sciurus vulgaris; Penteriani, 1997, 1999b). This index ranges from 0 (no overlap) to 1 (complete overlap).

\subsection{The effects of logging}

To evaluate the effects of logging on European goshawks, we again used three tests. For this purpose, we pooled Italian and French site data using the same variables as those for the above-mentioned nest trees and nesting stands: (1) a DFA tested for differences in structure between unlogged and logged stands: for the latter, we used the conditions of the site where the birds had most recently nested; (2) the Mann-Whitney U-test was used to determine significant differences in productivity of goshawk pairs reproducing in unlogged vs. logged stands; (3) a repeated-measures analysis of variance (Sokal and Rohlf, 1995) tested for differences in the number of young per breeding pair and for year effects between logged and unlogged stands, both for the same nesting stand before and after timber harvesting. We applied sequential Bonferroni's adjustment of $\alpha$ level (Rice, 1989) each time that we tested a hypothesis with multiple statistical tests. Values presented are means T S.D.

\section{Results}

\subsection{Comparisons between the Italian and French populations}

The Italian $(n=8)$ and French $(n=13)$ goshawk pairs showed no significant differences (DFA, P>0.05) in the physical structure of nesting stands. Likewise, the comparison between Italian and French data showed no significant differences in the number of young per breeding pair (1.6 0.9 and $1.4 \mathrm{~T} 0.9$, respectively, $\mathrm{U}=0.409, \mathrm{P}=0.68$; Mann-Whitney U-test), or in the number of young per successful pair $(1.9 \mathrm{~T} 0.6$ and $1.8 \mathrm{~T} 0.6$ respectively; $\mathrm{U}=0.501, \mathrm{P}=0.62$ ). The diet of both European populations showed a high overlap (Pianka's index=0.89).

Since there was no significant differences in the structure of the nesting stands, before and after logging, or in productivity or diet, we pooled both Italian and French nesting stands to evaluate the effects of logging on goshawks.

\subsection{The effects of logging}

By using the discriminant function analysis, we found significant differences $(\mathrm{P}<0.05)$ in structure between unlogged $(n=21)$ and logged $(n=13)$ nesting stands, based on three variables: \% canopy cover, distance between trees, and flight space. We obtained a correct classification for $21(100 \%)$ of the unlogged stands and $13(100 \%)$ of the logged ones. This classification was non random $\left(c^{2}=107.02, \mathrm{P}<0.001\right)$. Secondly, we found no difference in productivity of goshawk pairs reproducing in unlogged vs. logged stands (Table 1); and thirdly, when considering the same nesting stand, before and after timber harvesting, we found no difference in the number of young per breeding pair $(\mathrm{F}=1.33$, d.f. $=6,18, P=0.29)$ or in the year effect $(F=0.57$, d.f. $=5,20, P=0.69$ ), assuming the pair continued to occupy the nest stand in years following the logging.

During the study, we monitored the goshawk occupancy rate in nine nesting stands affected by the main felling steps after the light thinning (Table 2): almost all the goshawk pairs nesting in these stands moved away to reproduce only when the original structure was altered by $>30 \%$ (after the first two stages). In the only case in which a pair tried to reproduce again in the stand at the fourth overall felling stage (70\% clearance), it failed after egg-laying. Of the pairs that moved away, seven $(87.5 \%)$ moved to the nearest mature stand (maximum distance ca. $1.5 \mathrm{~km}$ ) and one was not found again. Three pairs $(42.9 \%)$ moved to the border

Table 1

Comparisons of goshawk productivity (xT S.D.; Mann-Whitney U-test) in unlogged $(n=21)$ vs. logged stands $(n=13)$

\begin{tabular}{lcrr}
\hline & $\begin{array}{l}\text { Unlogged } \\
\text { nesting } \\
\text { stands }\end{array}$ & $\begin{array}{r}\text { Logged } \\
\text { nesting } \\
\text { stands }\end{array}$ \\
\hline No. of young/breeding pair & $1.5 \mathrm{~T} 0.9$ & $\mathrm{U}=0.74, \mathrm{P}=0.46$ & $1.5 \mathrm{~T} 0.9$ \\
No. of young/successful pair & $1.9 \mathrm{~T} 0.6$ & $\mathrm{U}=1.26, \mathrm{P}=0.21$ & $1.8 \mathrm{~T} 0.6$ \\
\% Successful pairs & 77.4 & & 80.5 \\
\hline
\end{tabular}


Table 2

Relationship between felling stages in the shelterwood system (\% of timber harvesting) and nesting site desertion by goshawks $(n=9)$

\begin{tabular}{ll}
\hline Stage $(\%)$ & $\begin{array}{l}\text { Number of pairs moving away } \\
\text { from the nesting site } \mathrm{n}(\%)\end{array}$ \\
\hline $0-10$ & $0(0)$ \\
$10-30$ & $0(0)$ \\
$30-50$ & $8(88.9)$ \\
$50-70$ & $1(11.1)^{\mathrm{a}}$ \\
$70-100$ & No breeding pair in the stand
\end{tabular}

a The pair failed reproduction after egg-laying.

between the cut and unlogged stand after the 30\% felling, and successfully nested there for several years. No pair left its habitual nest site if the logging had only affected the surroundings of its nesting stand (from about $100 \mathrm{~m}$ to $<1 \mathrm{~km}$ ), also after definitive felling.

When the logging continued in April and May (brooding period), all nesting attempts $(n=5)$ failed, but logging during the late nestling and fledgling phase did not cause any measurable loss in reproduction $(n=16)$. Whether the nesting stand was unlogged or logged, egg laying always took place between 15and 25April in Italy, and between 1 and 10 April in France.

\section{Discussion}

Our results suggest that goshawks can tolerate some level of timber harvesting within the nesting stand in the two European regions that we analysed. Of critical importance for management, however, are the second and the third felling stages after initial thinning, which reduce the tree density and canopy cover by about 50 and $70 \%$ from the original. We conclude that goshawks have long-term fidelity to the nesting stand in the absence of severe habitat degradation, as long as the tree cover reduction does not exceed $30 \%$. The removal of more then $30 \%$ of the trees may increase the risks of predation, brood parasitism and exposure to bad weather conditions, and hence induce goshawks to leave their nesting stand (Robinson et al., 1995; Kenward, 1996).

The applicability of these results to other European goshawk populations should be validated by further investigations as our findings may be specific to shelterwood logging and to the areas involved in timber harvesting, or they may be affected by uncontrolled specific factors. Our analyses do not consider other factors (e.g. predation, disease, availability of food during winter and breeding period, competition, etc.) that play an equally important role in determining the settlement of a nesting pair.

This study showed that the adaptation of goshawks to logging was high in both European areas. This does not mean that timber harvesting has no impact on goshawk populations from the standpoint of landscape: Widen
(1997) reported that, in recent years, goshawks have declined in Fennoscandia due to forest fragmentation and reduction in the total amount of old-growth and mature stands and associated prey populations. Such large-scale changes may result in a deterioration of the quality of goshawk hunting ranges, and be a more important problem than nest site availability. Some studied European populations seem to be less sensitive to timber harvesting within nest stands than are North American ones (Kenward, 1996). Actually, CrockerBedford's study (1990) showed that even buffer zones, up to 200 ha with unlogged trees around nest trees, did not maintain goshawk reproduction or decreased productivity. Contrary to our data on nesting stand fidelity and productivity, he recorded North American occupancy rates to be $75-80 \%$ lower in areas where timber harvesting occurred around the above-mentioned buffer zones, and nest production was $94 \%$ lower. Moreover, it is worth stressing that his study was (1) focused on an area where the extent of the logging was similar to our study areas, and (2) light logging affected only the surroundings of the nesting stand, and not the nesting stand structure as in our study area.

\subsection{Conservation and management implications}

The findings from this study are encouraging, because they suggest that we can predict the logging stage of the shelterwood system when goshawks leave their nesting stand to search for a new nest site, and because conservation biologists could work jointly with foresters to manage woodland areas to preserve the mature stands closest to the logged ones (from $100 \mathrm{~m}$ to ca. $1 \mathrm{~km}$ ). As noted by Squires and Ruggiero (1996) for the United States, pre-commercial thinning might also be used in Europe to create forest stands similar to those needed by goshawks. A crucial element for the conservation of the species may be (1) the conservation or creation of mature stands on the goshawk's preferred north slope orientation (Penteriani and Faivre, 1997; Penteriani, 1999b), (2) spaced on the basis of the minimum average distance between breeding pairs. Similar recommendations were proposed in a descriptive study on nesting habitat preferences of goshawks in Spain (Manosa, 1993). The best way to preserve goshawk nesting pairs seems to be the creation of a mosaic of neighbouring logged and unlogged areas inside a forested landscape, like the one typical of the shelterwood system, although each local situation should be evaluated before planning forest management.

Petty (1996) proposed an experimental buffer zone of at least 5ha around the nest tree, because nesting stands should not be isolated blocks in a logged area. Our experimental results seem to validate this recommendation, although the buffer zone might be reduced to 1-2 ha in areas managed with the shelterwood system. 
Moreover, autumn and winter logging in the nesting stand does not appear to affect goshawk occupancy and productivity as long as the cover reduction does not exceed the $30 \%$ threshold, and large blocks of neighbouring stands are not concurrently affected by logging. Our analyses of the stand structure selected by goshawks (Penteriani and Faivre, 1997; Penteriani, 1999b), revealed that their nests are always placed inside the older portion of a tall tree forest, which lies inside a less mature portion: the nest tree seems to represent the focus of the overall structural system of the nest site, from which size and distinctive features decrease with distance from the nest. These behavioural and structural data may combine to show that the mature forest portion needed by goshawks to reproduce successfully is limited in space (about $1 \mathrm{ha}$ ). The effects of logging on the species may also be unimportant if the logging involves an area of ca. $100 \mathrm{~m}$ away from the nest tree (up to the $30 \%$ threshold and avoiding logging during incubation). Crocker-Bedford (pers. commun.) states that if adequate hunting habitat persists in a home range, then nest philopatry could induce a goshawk to remain even after a nesting stand no longer has the original structure.

Forestry operations within goshawk nesting stands should be avoided from February to July (inclusive). If an extension of the logging is absolutely necessary, then forest works should stop at least 1-2 weeks before egglaying, and start again during the nestling period. We recommend future comparative studies of nemoral (deciduous) vs. boreal (coniferous) European areas, as well as between Palearctic and Nearctic goshawk populations. Such comparisons will allow us (1) to directly measure goshawk responses to silvicultural treatments and management recommendations, and (2) to evaluate their responses to logging, in order to identify possible differences in the process of species adaptation during the Pleistocene glaciations, and to determine the timescales and extent of anthropogenic pressures on forested habitats (Monkkonen and Welsh, 1994; Martin and Clobert, 1996; Niemi and Hanowski, 1997a). Particular attention could be paid to the possible different responses to logging within nest stands, in the nest stands surrounding only, as well as when the logging interests both these situations. There is a priority need to understand whether goshawks can cope with a small amount of logging within their nesting stands, as long as not too much habitat in their home ranges is degraded in terms of prey abundance and available hunting territory.

\section{Acknowledgements}

The research in Italy was financially supported by the Abruzzi (Research Centre of Apennine Ecology) and Majella National Parks. We thank F. Liberatori, F.
Pinchera, M. Cerasoli, M. Pellegrini, G. Boisson, M. Mathiaut and H. Cazassus for their help in the field work, and S. Quinto, D. Brochard and F. Habert (O.N.F. - Office National des Forets) for providing data and useful insights into forest treatments. P. Alibert, L. Boitani, D.C. Crocker-Bedford, W. M. Giuliano, T. Nygard, P. Olsen, I. Tailor, K. Titus, and S. Saraceni provided helpful comments on the manuscript.

\section{References}

Block, W.M., Morrison, M.L., Reiser, M.H. (Ed.), 1994. The Northern Goshawk: Ecology and Management. Studies in Avian Biology 16. Cooper Ornithological Society.

Cooper, M., Stevens, V. 2000. A Review of the Ecology, Management and Conservation of the Northern Goshawk in British Columbia. Wildlife Bulletin B-101. Ministry Environment, Wildlife Branch, Victoria.

Crocker-Bedford, D.C., 1990. Goshawk reproduction and forest management. Wildlife Society Bulletin 18, 262-269.

Crocker-Bedford, D.C., 1998. The value of demographic and habitat studies in determining the status of Northern Goshawk (Accipiter gentilis atricapillus) with special reference to Crocker-Bedford (1990) and Kennedy (1997). Journal of Raptor Research 32, 329-336.

Crocker-Bedford, D.C., Chaney, B., 1988. Characteritics of Goshawk nesting stands. In: Glinski, R.L., Pendleton, B.G., Moss, M.B., LeFranc, M.N., Millsap, B.A., Hoffman, S.W. (Eds.), Proceedings of the Southwest Raptor Management Symposium and Workshop. National Wildlife Federation Scientific and Technical Series 11, USA, pp. 210-217.

Ferry, C., Frochot, B., 1990. Bird communities of the forest of Burgundy and the Jura (Eastern France). In: Keast, A. (Ed.), Biogeography and Ecology of Forest Bird Communities. SPB Academic Publishing, The Hague, pp. 183-195.

Forsman, D., Ehrnsten, B., 1985. Is the goshawk Accipiter gentiles declining? Lintumies 20, 83-88.

Graham, R.T., Reynolds, R.T., Reiser, M.H., Basset, R.L., Boyce, D.A., 1994. Sustaining forest habitat for the Northern Goshawk: a question of scale. In: Block, W.M., Morrison, M.L., Reiser, M.H. (Eds.), The Northern Goshawk: Ecology and Management. Studies in Avian Biology 16. Cooper Ornithological Society, pp. 12-17.

Hall, P.A., 1984. Characterization of Nesting Habitat of Goshawks (Accipiter gentilis) in Northwestern California. MS thesis, Humboldt State University, Arcata.

Harris, L.D., Kangas, P., 1988. Reconsideration of the Habitat Concept. 53nd North American Wildlife Natural Resources Conference, pp. 137-144.

Harris, E., Harris, J., 1991. Wildlife Conservation in Managed Woodlands and Forests. Basil Blackwell Ltd, Oxford.

Iverson, G.C., Hayward, G.D., Titus, K., DeGayner, E., Lowell, R.E., Crocker-Bedford, D.C., Schempf, P.F., Lindell, J., 1996. Conservation assessment for the northern goshawk in southeast Alaska. General Technical Report PNW-GTR-387. US Forest Service.

Kennedy, P.L., 1988. Habitat characteristics of Cooper's Hawks and Northern Goshawks nesting in New Mexico. Proceedings of the Southwest Raptor Management Symposium and Workshop. National Wildlife Federation, Washington, DC, pp. 218-227.

Kenward, R.E., Marcstrom, V., Karlbom, M., 1991. The goshawk (Accipiter gentilis)l as predator and renewable resource. Gibier Faune Sauvage 8, 367-378.

Kenward, R.E., 1996. Goshawk adaptation to deforestation: does Europe differ from north America? In: Bird, D.M., Varland, D.E., Negro, J.J. (Eds.), Raptors in Human Landscape. Academic Press, London, pp. 233-243. 
Manosa, S., 1993. Seleccion de habitat de nidificacion en el Azor (Accipiter gentilis). Recomendaciones para su gestion. Alytes 6, 125136.

Marti, C.D., 1987. Raptor food habits studies. In: Giron Pendleton, B.A., Millsap, B.A., Cline, K.W., Bird, D.M. (Eds.), Raptor Management Techniques Manual. National Wildlife Federation 10, Washington, DC, pp. 67-80.

Martin, T.E., Clobert, J., 1996. Nest predation and avian life-history evolution in Europe versus North America: a possible role of humans? American Naturalist 147, 1028-1046.

McCarthy, C., Carrier, W.D., Laudenslayer, W.F., 1987. Coordinating timber management activities with raptor nesting habitat requirements. In: Proceedings Western Raptor Management Symposium and Workshop. National Wildlife Federation, Washington DC, pp. 229-235.

Monkkonen, M., Welsh, D.A., 1994. A biogeographical hypothesis on the effects of human caused landscape changes on the forest bird communities of Europe and North America. Annales Zoologica Fennici 31, 61-70.

Niemi, G.J., Hanowski, J.M., 1997a. Concluding remarks on raptor responses to forest management: a holarctic perspective. Journal of Raptor Research 31, 191-196.

Niemi, G.J., Hanowski, J.M., 1997b. Raptor responses to forest management: a holarctic perspective. Journal of Raptor Research 31, 93-94.

Penteriani, V., 1997. Long-term study of a goshawk breeding population on a mediterranean mountain (Abruzzi Apennines, Central Italy): density, breeding performances and diet. Journal of Raptor Research 31, 308-312.

Penteriani, V., 1999a. Dawn and morning Goshawk courtship vocalizations as a method for detecting nest sites. Journal of Wildlife Management 63, 511-516.

Penteriani, V., 1999. Echelles et Facteurs de la Selection de l'Habitat de Nidification: le Cas de l'Autour des Palombes Accipiter gentilis. PhD Dissertation, Burgundy University, Dijon.

Penteriani, V., Faivre, B., 1997. Breeding density and nest site selection in a Goshawk Accipiter gentiles population of the Central Apennines (Abruzzo, Italy). Bird Study 44, 136-145.

Peterken, G.F., 1996. Natural Woodland. Ecology and Conservation in Northern Temperate Regions. Cambridge University Press, Cambridge.
Petty, S.J., 1996. Reducing Disturbance to Goshawks During the Breeding Season. Forestry Commission, Research Information Note 267, Edinburgh.

Petty, S.J., 1998. Ecology and Conservation of Raptors in Forests. Forestry Commission Bulletin 118, London.

Reynolds, R.T., Meslow, E.C., Wight, H.M., 1982. Nesting habitat of coexisting accipiter in Oregon. Journal of Wildlife Management 46, 124-138.

Reynolds, R.T., Graham, R.T., Reiser, M.H., Basset, R.L., Kennedy, P.L., Boyce, D.A., Jr., Goodwin, G., Smith, R., Fisher, E.L., 1992. Management Recommendations for the Northern Goshawk in the Southwestern United States. US Forest Service General Technical Report RM-217.

Rice, W.R., 1989. Analyzing tables of statistical tests. Evolution 43, 223-225.

Robinson, S.K., Thompson III, F.R., Donovan, T.M., Whitehead, D.R., Faaborg, J., 1995. Regional forest fragmentation and the nesting success of migratory birds. Science 267, 1987-1990.

Sokal, R.R., Rohlf, F.J., 1995. Biometry, the Principles and Practice of Statistics in Biological Research, 3rd Edition. Freeman, New York.

Squires, J.R., Ruggiero, L.F., 1996. Nest-site preference of northern goshawks in southcentral Wyoming. Journal of Wildlife Management 60, 170-177.

Steenhof, K., 1987. Assessing raptor reproductive success and productivity. In: Giron Pendleton, B.A., Millsap, B.A., Cline, K.W., Bird, D.M. (Eds.), Raptor Management Techniques Manual. National Wildlife Federation 10, Washington DC, pp. 157-170.

Sulli, C., Bernoni, M., 1993. Primi riscontri ai criteri di gestione delle risorse forestali adottati nel Parco Nazionale d'Abruzzo. Colloques phytosociologiques - Camerino. Ecologia del paesaggio 21, 373-378.

Thomas, J.W., Forsman, E.D., Lint, J.B., Meslow, E.C., Noon, B.R., Verner, J., 1990. A Conservation strategy for the northern spotted owl. Report of the Interagency Scientific Committee to Address the Conservation of the Northern Spotted Owl, USA.

Toyne, E.P., 1997. Nesting chronology of northern goshawks (Accipiter gentiles) in Wales: implications for forest management. Forestry 70, 121-126.

Widen, P., 1997. How, and why, is the Goshawk (Accipiter gentilis) affected by modern forest management in Fennoscandia. Journal of Raptor Research 31, 107-113. 